\title{
FORMS OF INORGANIC PHOSPHORUS IN SOIL UNDER DIFFERENT LONG TERM SOIL TILLAGE SYSTEMS AND WINTER CROPS(1)
}

\author{
Tales Tiecher ${ }^{(2)}$, Danilo Rheinheimer dos Santos ${ }^{(3)}$, João Kaminski(4) \& \\ Ademir Calegari ${ }^{(5)}$
}

\begin{abstract}
SUMMARY
The cultivation of crops with different capacity of $P$ uptake and use under long-term soil tillage systems can affect the distribution of $P$ cycling and inorganic forms in the soil, as a result of higher or lower use efficiency of $\mathbf{P}$ applied in fertilizers. The purpose of this study was to evaluate the effect of long-term cultivation of different winter species under tillage systems on the distribution of inorganic $P$ forms in the soil. In 1986, the experiment was initiated with six winter crops (blue lupin, hairy vetch, oat, oilseed radish, wheat and fallow) on a Rhodic Hapludox in southwestern Paraná, under no-tillage (NT) and conventional tillage (CT). The application of phosphate fertilizer in NT rows increased inorganic $P$ in the labile and moderately labile forms, and soil disturbance in CT redistributed the applied $P$ in the deeper layers, increasing the moderately labile $P$ concentration in the subsurface layers. Black oat and blue lupin were the most efficient P-recyclers and under NT, they increased the labile $P$ content in the soil surface layers.
\end{abstract}

Index terms: no tillage, conventional tillage, lability, phosphorus fractionation, cover crops, soil management.

(1) Part of the Dissertation of the first author presented to the Graduate Program in Soil Science, Universidade Federal de Santa Maria (Federal University of Santa Maria) - UFSM. Received for publication in February 4, 2011 and approved in November 8, 2011.

(2) Doctoral candidate in Soil Science, Rural Sciences Center - CCR, Universidade Federal de Santa Maria - UFSM. 1000 Roraima Ave, Camobi, CEP 97105-900 Santa Maria (RS) Brazil. CNPq Scholarship. E-mail: tales.t@hotmail.com

(3) Associate Professor of the Soil Department, UFSM. CNPq Scholarship. E-mail: danilonesaf@gmail.com

(4) Professor of the Soil Department, UFSM. CNPq Scholarship. E-mail: jk@smail.ufsm.br

(5) Researcher of the Agronomic Institute of Paraná - IAPAR. Pólo Regional de Ponta Grossa, Caixa Postal 129, CEP 84001-970 Ponta Grossa (PR). E-mail: calegari@iapar.br 


\title{
RESUMO: FORMAS DE FÓSFORO INORGÂNICO NO SOLO SOB DIFE- RENTES PREPAROS DE SOLO E CULTURAS DE INVERNO POR UM LONGO PERÍODO
}

\begin{abstract}
$O$ cultivo de plantas com diferentes habilidades de absorção e utilização de $P$ sob diferentes sistemas de preparo de solo por um longo período de tempo pode alterar a ciclagem e a distribuição das formas de $P$ inorgânico no solo, como resultado de maior ou menor eficiência de utilização do $P$ adicionado via fertilizantes. O objetivo deste trabalho foi avaliar o efeito de longo período de cultivo de diferentes espécies de inverno sob diferentes sistemas de preparo de solo na distribuição das formas de P inorgânico do solo. Em 1986, foi estabelecido o experimento com seis tratamentos de inverno (tremoço-azul, ervilhacapeluda, aveia-preta, nabo forrageiro, trigo e pousio) implantados num Latossolo Vermelho aluminoférrico na região sudoeste do Paraná, sob sistema plantio direto (SPD) e sistema de cultivo convencional (SCC). A adição de fertilizantes fosfatados na linha de semeadura no SPD promoveu aumento de P inorgânico, nas formas lábeis e moderadamente lábeis, e o revolvimento do solo no SCC redistribuiu o $P$ aplicado em profundidade, promovendo aumento no teor de P moderadamente lábil no solo das camadas subsuperficiais. A aveiapreta e o tremoço-azul foram mais eficientes na ciclagem de $P$ e, quando cultivados sob SPD, aumentaram o teor de P lábil no solo das camadas superficiais.
\end{abstract}

Termos de indexação: sistema plantio direto, sistema de cultivo convencional, labilidade, fracionamento do fósforo, culturas de cobertura, manejo de solo.

\section{INTRODUCTION}

In natural ecosystems on young, little weathered soils, $\mathrm{P}$ availability is controlled by the dissolution of primary mineral phosphate (Tiessen et al., 1984). However, in more weathered soils, the decomposition and mineralization of forest litter and soil organic matter come to be the primary sources of $\mathrm{P}$, since mineral $\mathrm{P}$ is retained mostly in less available forms (Vincent et al., 2010). In the conversion of natural ecosystems to agricultural areas, the native plants, well-adapted to low levels of available $\mathrm{P}$ are substituted by crops with high nutrient requirements, with lower capacity and strategies for $\mathrm{P}$ uptake and use. Therefore, in view of the crop demand these environments are generally P-deficient, which limits yields and requires phosphate supply by fertilization.

In production systems with regular fertilizer application, the total $\mathrm{P}$ content in the soil increases. The form in which the applied phosphate accumulates in the soil depends on the applied and exported amount of $\mathrm{P}$, and on the soil type and management. When the soil is cultivated for a long time under no-tillage (NT), $\mathrm{P}$ is accumulated in the soil surface (Redel et al., 2007; Zamuner et al., 2008), since the fertilizer is applied in the planting row, with minimum soil disturbance and distributed in a lower soil volume than in conventional tillage (CT) (Rheinheimer \& Anghinoni, 2001). With this accumulation of $\mathrm{P}$ under NT, the sites of higher $\mathrm{P}$ affinity in the soil surface layer are gradually saturated, decreasing the binding energy of $\mathrm{P}$ and increasing its availability (Rheinheimer et al., 2003).

Due to the differences in the chemical nature and binding energy of $\mathrm{P}$ in the soil, its desorption capabilities can differ. Routine methods usually estimate $\mathrm{P}$ availability by a single extraction of available $\mathrm{P}$ with chemical extractants, such as Mehlich-1 or anion exchange resin (AER) (CQFSRS/ SC, 2004). However, to evaluate the potential availability, a single extraction can be insufficient. In this sense, Gatiboni et al. (2002) reported that the first extraction with AER from a clay soil estimated only $37 \%$ of potentially available $\mathrm{P}$, and that seven successive extractions were necessary to exhaust it completely. Rheinheimer et al. (2000) found that after 10 successive extractions with AER, the inorganic $\mathrm{P}$ extracted by $\mathrm{NaOH}(0.1$ and $0.5 \mathrm{~mol} \mathrm{~L}^{-1}$ ) was the main buffer of the potentially available $\mathrm{P}$, approximately $80 \%$. Therefore, data on $\mathrm{P}$ accumulation or depletion in the long term may be obtained with stronger extractants, such as $0.1 \mathrm{~mol} \mathrm{~L}^{-1} \mathrm{NaOH}$ (Kuo et al., 2005; Gatiboni et al., 2007; Takeda et al., 2009).

The $\mathrm{P}$ uptake capacity differs among crops. These differences are the result of the varied acquisition strategies, as expressed in differences in the root morphology (root density, length, diameter, hair), in varying degrees among the species, besides differences in the mycorrhiza associations, and in the $\mathrm{pH}$ of the rhizosphere and exudation of lowmolecular-weight phosphatases and organic acids (Lajtha \& Harrison, 1995; Bayon et al., 2006; Wang 
et al., 2008; Li et al., 2010; Rose et al., 2010). These differences may affect the processes of dissolution/ precipitation, adsorption/desorption, diffusive transport, soil/root contact and $\mathrm{P}$ mineralization (Horst et al., 2001. However, for Rheinheimer \& Anghinoni (2001), the effect of growing different annual crop species on the dynamics of $\mathrm{P}$ inorganic fractions was low, restricted to the accumulation of more labile $\mathrm{P}$ forms in grass treatments without $\mathrm{N}$ application, due to the lower $\mathrm{P}$ export in low grain yields.

The purpose of this study was to evaluate (i) the effect of different soil tillage systems and (ii) the effect of different winter species on the distribution of soil inorganic $\mathrm{P}$ forms in a very clayey soil in long term cultivation.

\section{MATERIAL AND METHODS}

A long-term experiment was established in 1986 at the Experimental Station of Pato Branco of the Agronomic Institute of Paraná (IAPAR), in southwestern Paraná State, Brazil (52 41' W, $26^{\circ} 07^{\prime} \mathrm{S}, 700 \mathrm{~m}$ asl). The soil of the experimental site is a very acid Oxisol (Rhodic Hapludox), with high clay content (mineralogical composition in Table 1). According to Köppen, the climate was classified as $\mathrm{Cfb}$ - subhumid tropical. The average monthly temperature and rainfall at the experimental station in the period 1979-2009 and in 2009, respectively, are listed in table 2 .

The experimental area was covered by subtropical forest until 1976, when it was cleared to grow maize (Zea mays L.) and beans (Phaseolus vulgaris L.) for 10 years in a conventional system, without terracing, prior to the experiment. From the winter of 1986, experimental treatments combining different soil tillage and winter cover crops were initiated in the area, in a split-plot design in three blocks. The winter cover crops consisted of: blue lupin (Lupinus angustifolius L.), hairy vetch (Vicia villosa Roth), black oat (Avena strigosa Schreb.), radish (Raphanus sativus L.), winter wheat (Triticum aestivum L.), and fallow. Tillage treatments were conventional tillage (CT), with one disk plow and two disk harrowings, and continuous no-tillage (NT).

These winter cover crops were sown in the main plots (in the years 1986-1990, 1992-1994, 1999-2001, 2005 and 2008). In some winter growing seasons (1991, 1995, 1996, 1998, 2006, and 2009), black oat was planted in the entire experimental area; in 1993 the soil was left fallow in the winter; and black oat + radish were sown in all main plots (in 1997, 2002, 2003, 2004, and 2007). The cover crops

Table 1. Texture and mineralogy of a Rhodic Hapludox, in an experimental area after 23 years of different soil managements and winter crops

\begin{tabular}{|c|c|c|c|c|c|c|c|c|c|c|c|c|}
\hline \multirow[b]{2}{*}{ Horizon } & \multicolumn{3}{|c|}{ Texture $(1)$} & \multicolumn{7}{|c|}{ Mineralogy(2) } & \multicolumn{2}{|c|}{ Oxalate $^{(3)}$} \\
\hline & Clay & Silt & Sand & $1: 1^{(4)}$ & $2: 1^{(5)}$ & $\mathrm{Fe}_{2} \mathrm{O}_{3}$ & Maghemite & Hematite & Goethite & Gibbsite & $\mathrm{Fe}$ & $\mathrm{Al}$ \\
\hline & & & & & & & g kg & & & - & & \\
\hline $\mathrm{A}(0-1 \mathrm{~m})$ & 720 & 140 & 140 & 680 & 132 & 140 & 130 & 510 & 360 & 50 & 55 & 22 \\
\hline $\mathrm{Bw}(1-2 \mathrm{~m})$ & - & - & - & 710 & 128 & 140 & 120 & 540 & 340 & 20 & - & - \\
\hline
\end{tabular}

(1) Calegari (2006). ${ }^{(2)}$ Costa (1996). ${ }^{(3)}$ Soil layer 0-0.40 m. ${ }^{(4)}$ Kaolinite and halloysite. ${ }^{(5)}$ Vermiculite and/or montmorillonite.

Table 2. Mean temperature and rainfall in an experimental area in Pato Branco, southeastern region of Paraná, averaged over 1979-2009 and in 2009

\begin{tabular}{|c|c|c|c|c|c|c|c|c|c|c|c|c|c|}
\hline Period & Jan & Feb & Mar & Apr & May & Jun & Jul & Aug & Sep & Oct & Nov & Dec & Year \\
\hline & \multicolumn{13}{|c|}{ Temperature $\left({ }^{\circ} \mathrm{C}\right)$} \\
\hline 1979-2009 & 22.5 & 22.2 & 21.4 & 19.2 & 15.7 & 14.4 & 14.2 & 16.1 & 16.8 & 19.5 & 21.0 & 22.2 & 18.8 \\
\hline \multirow[t]{2}{*}{2009} & 21.3 & 22.8 & 22.3 & 20.2 & 16.5 & 12.6 & 12.9 & 16.0 & 16.7 & 19.2 & 23.3 & 22.9 & 18.9 \\
\hline & \multicolumn{13}{|c|}{ Rainfall (mm) } \\
\hline 1979-2009 & 183 & 170 & 124 & 179 & 202 & 161 & 142 & 116 & 175 & 254 & 189 & 183 & 2.077 \\
\hline 2009 & 136 & 83 & 151 & 84 & 247 & 127 & 134 & 154 & 274 & 327 & 128 & 140 & 1.985 \\
\hline
\end{tabular}

Source: IAPAR Weather Station, Pato Branco, Paraná. 
were cut at flowering with a rolling stalk chopper (lupin, hairy vetch, oats and radish). Herbicide was applied in the fallow treatment to kill weeds. In some cases, cutting was completed with herbicide application. Wheat grain was harvested until 1995 (7 crops). After wheat harvest, straw was left on the soil surface as mulch or incorporated before planting the summer crop. Summer crops of maize and soybean were planted after the winter species. Between 1986 and 2009, maize was planted in 9 summer growing seasons (1986, 1987, 1988, 1992, 1994, 1996, 1999, 2003, and 2008) and soybean in 13 (1989, 1990, 1991, 1993, 1995, 1997, 1998, 2000, 2001, 2002, 2004, 2005, and 2007). In 2006 the soil was left fallow in the summer.

Summer crops were fertilized each year; the total amount of fertilizer applied in the 23 years was $1510 \mathrm{~kg} \mathrm{ha}^{-1} \mathrm{P}_{2} \mathrm{O}_{5}, 805 \mathrm{~kg} \mathrm{ha}^{-1} \mathrm{~K}_{2} \mathrm{O}$, and $501 \mathrm{~kg} \mathrm{ha}^{-1}$ $\mathrm{N}$. Generally, the $\mathrm{P}, \mathrm{K}$ and one-third of the $\mathrm{N}$ fertilizer were applied at planting, and two-thirds of N 45 days after planting. During this period, lime was applied in six years $(1.0 ; 2.0 ; 3.0 ; 1.5 ; 2.0$; and $2.0 \mathrm{Mg} \mathrm{ha}{ }^{-1}$ of dolomitic lime in all plots, in 1989, 1992, 1995, 1999, 2001 and 2006, respectively), with a total amount of $11.5 \mathrm{Mg} \mathrm{ha}{ }^{-1}$.

Soil was sampled in October 2009, at the beginning of black oat flowering. Two trenches were opened per plot $(0.5 \times 0.5 \mathrm{~m})$ and soil collected from five layers: $0-0.05 ; 0.05-0.10 ; 0.10-0.20$; $0.20-0.30$; and $0.30-0.40 \mathrm{~m}$. The subsamples of the two trenches of each plot were mixed to form a composite sample. Soil was also sampled in three trenches from the adjacent undisturbed forest, for comparison. The soil samples were dried at $\pm 60^{\circ} \mathrm{C}$, sieved through a $2 \mathrm{~mm}$ screen and stored. Undisturbed soil samples of each layer from one trench per plot were collected with metal cylinders $(0.03 \times 0.0612 \mathrm{~m})$, to determine the soil bulk density.

Soil inorganic $\mathrm{P}$ forms were estimated by fractionation, as described by Hedley et al. (1982) and modified by Rheinheimer (2000). The P forms were sequentially extracted by the following extractants: anion exchange resin (AER) (AR 103 QDP 434 Ionics Inc.), $\mathrm{NaHCO}_{3} 0.5 \mathrm{~mol} \mathrm{~L}^{-1}$ at $\mathrm{pH}$ 8.5, $0.1 \mathrm{~mol} \mathrm{~L}^{-1} \mathrm{NaOH}, 1.0 \mathrm{~mol} \mathrm{~L}^{-1} \mathrm{HCl}$, and $0.5 \mathrm{~mol} \mathrm{~L}^{-1}$ $\mathrm{NaOH}$. The residual soil was divided into two parts. In one, the total $\mathrm{P}$ was estimated by digestion with $\mathrm{H}_{2} \mathrm{SO}_{4}$ and $\mathrm{H}_{2} \mathrm{O}_{2}$ in the presence of saturated $\mathrm{MgCl}_{2}$ (Brookes \& Powlson, 1982) and in the other, organic $\mathrm{P}$ was estimated by the ignition method (Olsen \& Sommers, 1982). Thus, the residual inorganic $P$ was obtained by the difference between the total $\mathrm{P}$ and the residual organic $\mathrm{P}$. The inorganic $\mathrm{P}$ extracted by AER and $\mathrm{NaHCO}_{3}$ was considered to be labile; the inorganic $\mathrm{P}$ extracted by $\mathrm{NaOH}$ was considered moderately labile and the $\mathrm{P}$ extracted by $\mathrm{HCl}$ and residual inorganic $\mathrm{P}$ forms were considered nonlabile.
The $\mathrm{P}$ desorption capability was evaluated (soil layers $0-0.05,0.05-0.10$ and $0.10-0.20 \mathrm{~m}$ ) by successive extractions with AER, by filling $0.200 \mathrm{~g}$ of each soil sample into $15 \mathrm{~mL}$ Falcon tubes, in triplicate, with $10 \mathrm{~mL}$ of distilled water and one sheet of bicarbonate-saturated AER. The suspension was stirred for $16 \mathrm{~h}$ in an end-overend shaker at $\pm 25^{\circ} \mathrm{C}$. The resin sheets were then removed and washed with a distilled water flush and then eluted in $10 \mathrm{~mL}$ of $0.5 \mathrm{~mol} \mathrm{~L}^{-1} \mathrm{HCl}$. The operation was repeated until the amount of extracted $\mathrm{P}$ stabilized near zero. With the values of cumulative desorbed $\mathrm{P}$, the equation of first-order kinetics proposed by McKean \& Warren (1996) was modified as follows:

$$
\mathrm{P} \text { desorbed }=\beta-(\beta-\alpha)^{-k t}
$$

where $\beta$ is the maximum amount desorbed or potentially available $\mathrm{P}, \alpha$ is the amount of $\mathrm{P}$ desorbed in the first extraction, $k$ is the desorption rate constant, $t$ is the extraction time.

The inorganic $\mathrm{P}$ was extracted with distilled water by stirring $1.000 \mathrm{~g}$ of soil in $10 \mathrm{~mL}$ of distilled water for $2 \mathrm{~h}$ in a horizontal shaker. Total $\mathrm{P}$ was estimated by digestion with $\mathrm{H}_{2} \mathrm{SO}_{4}$ and $\mathrm{H}_{2} \mathrm{O}_{2}$ in the presence of saturated $\mathrm{MgCl}_{2}$ (Olsen \& Sommers, 1982). The inorganic $P$ in the acid extracts was determined according to the method of Murphy \& Riley (1962) and in the alkali extracts as proposed by Dick \& Tabatabai (1977).

The soil $\mathrm{P}$ balance was assessed considering the amount of $\mathrm{P}$ applied, the amount of $\mathrm{P}$ exported and the content of potentially available $\mathrm{P}$ for the following crop combinations: a) black oat/lupin under NT; b) vetch/oilseed radish/fallow under NT; c) wheat under NT; and d) average of the crops under CT. The amount applied was calculated based on the amount applied in each summer crop and the number of crops between 1986 and 2009, and the amount of $\mathrm{P}$ exported was calculated according to the average yield of each crop during the experimental period and the average $P$ grain content. The amount of potentially available $\mathrm{P}$ in the $0-0.20 \mathrm{~m}$ soil layer was calculated based on the amount of potentially available $\mathrm{P}(\beta)$ obtained by the McKean \& Warren (1996) equation, soil density and thickness of each layer. The relationship between $\mathrm{P}$ applied and potentially available $\mathrm{P}$ plus $\mathrm{P}$ exported was considered as recovered $\mathrm{P}$. The $\mathrm{P}$ losses by erosion and the amount of $\mathrm{P}$ applied and exported before the beginning of the experiment (1976 to 1986) were not considered in the balance.

A statistical model of three-factor randomized blocks with three replications was used. Data were subjected to analysis of variance, in a split-split plot design (two soil managements $\mathrm{x}$ six cropping sequences $\mathrm{x}$ five soil layers). The tillage systems 
were treated as main plots, the winter crops as split plots and soil layers as split-split-plots. When the treatment effects were significant at $5 \%$ probability of error by the $\mathrm{F}$ test, the differences between means of tillage systems, winter crops and soil layers were compared by Tukey's test $(p<0.05)$. The statistical analysis were performed with Assistat software, version 7.6 Beta 2011 (Silva \& Azevedo, 2006).

\section{RESULTS AND DISCUSSION}

\section{Effect of tillage system}

Under NT, the content of inorganic $\mathrm{P}$ recovered by all extractors in the $0-0.05 \mathrm{~m}$ soil layer was higher than in the soil under CT, except for the residual fraction (Table 3 ). In the $\mathrm{CT}$, the content

Table 3. Inorganic and total phosphorus forms after 23 years of different soil managements of a Rhodic Hapludox

\begin{tabular}{|c|c|c|c|c|c|}
\hline \multirow{2}{*}{$\begin{array}{c}\text { Soil } \\
\text { management }\end{array}$} & \multicolumn{5}{|c|}{ Soil depth (m) } \\
\hline & $0-0.05$ & $0.05-0.10$ & $0.10-0.20$ & $0.20-0.30$ & $0.30-0.40$ \\
\hline & \multicolumn{5}{|c|}{$\mathrm{m}$} \\
\hline & \multicolumn{5}{|c|}{ Inorganic $\mathrm{P}$ extracted by distilled water $\left(\mathrm{mg} \mathrm{kg}^{-1}\right)$} \\
\hline NT & $1.49 \mathrm{aA}^{* *}$ & $0.48 \mathrm{aB}$ & $0.44 \mathrm{aB}$ & $0.29 \mathrm{aB}$ & $0.13 \mathrm{aB}$ \\
\hline $\mathrm{CT}$ & $0.48 \mathrm{bA}$ & $0.44 \mathrm{aA}$ & $0.41 \mathrm{aA}$ & $0.30 \mathrm{aA}$ & $0.20 \mathrm{aA}$ \\
\hline Forest $(1)$ & 0.75 & 0.62 & 0.34 & 0.12 & 0.12 \\
\hline & \multicolumn{5}{|c|}{ Inorganic $\mathrm{P}$ extracted by anion exchange resin $\left(\mathrm{mg} \mathrm{kg}^{-1}\right)$} \\
\hline NT & $44.6(2.4)^{(2)} \mathrm{aA}^{* *}$ & $11.7(0.8) \mathrm{aB}$ & $3.4(0.3) \mathrm{aC}$ & $1.2(0.1) \mathrm{aC}$ & $0.8(0.1) \mathrm{aC}$ \\
\hline $\mathrm{CT}$ & $10.6(0.7) \quad \mathrm{bA}$ & $9.3(0.6) \mathrm{aA}$ & $6.4(0.4) \mathrm{aAB}$ & $2.5(0.2) \mathrm{aB}$ & $1.1(0.1) \mathrm{aB}$ \\
\hline Forest & $11.5(0.9)$ & $4.4(0.4)$ & $1.9(0.2)$ & $1.2(0.1)$ & $\begin{array}{l}1.0(0.1) \\
\quad \mathrm{CV}=31.41 \%\end{array}$ \\
\hline & \multicolumn{5}{|c|}{ Inorganic $\mathrm{P}$ extracted by $0.5 \mathrm{~mol} \mathrm{~L}^{-1} \mathrm{NaHCO}_{3}\left(\mathrm{mg} \mathrm{kg}^{-1}\right)$} \\
\hline NT & $11.6(0.6)^{(2)} \mathrm{aA}$ & $5.7(0.4) \mathrm{aB}$ & $3.6(0.3) \mathrm{aBC}$ & $2.9(0.2) \mathrm{aC}$ & $2.6(0.2) \mathrm{aC}$ \\
\hline $\mathrm{CT}$ & $5.7(0.4) \mathrm{bA}$ & $5.3(0.4) \mathrm{aAB}$ & $4.6(0.3) \mathrm{aAB}$ & $3.4(0.3) \mathrm{aAB}$ & $3.1(0.3) \mathrm{aB}$ \\
\hline Forest & $8.4(0.7)$ & $5.1(0.4)$ & $3.2(0.3)$ & $2.8(0.3)$ & $\begin{array}{l}3.0(0.3) \\
\quad \mathrm{CV}=20.66 \%\end{array}$ \\
\hline & \multicolumn{5}{|c|}{ Inorganic $\mathrm{P}$ extracted by $0.1 \mathrm{~mol} \mathrm{~L}^{-1} \mathrm{NaOH}\left(\mathrm{mg} \mathrm{kg}^{-1}\right)$} \\
\hline NT & $59.8(3.2)^{(2)} \mathrm{aA}^{* *}$ & $37.2(2.5) \mathrm{aB}$ & $30.8(2.4) \mathrm{aC}$ & $24.6(2.1) \mathrm{bD}$ & $22.7(2.0) \mathrm{aD}$ \\
\hline $\mathrm{CT}$ & $36.4(2.4)$ bA & $35.5(2.4) \mathrm{aA}$ & $33.9(2.4) \mathrm{aA}$ & $28.7(2.2) \mathrm{aB}$ & $25.8(2.2) \mathrm{aB}$ \\
\hline Forest & $42.2(3.3)$ & $30.4(2.6)$ & $27.9(2.5)$ & $26.8(2.5)$ & $\begin{array}{l}27.3(2.6) \\
\quad \mathrm{CV}=16.03 \%\end{array}$ \\
\hline & \multicolumn{5}{|c|}{ Inorganic $\mathrm{P}$ extracted by $1.0 \mathrm{~mol} \mathrm{~L}{ }^{-1} \mathrm{HCl}\left(\mathrm{mg} \mathrm{kg}^{-1}\right)$} \\
\hline NT & $16.8(0.9)^{(2)} \mathrm{aA}^{*}$ & $5.5(0.4) \mathrm{aB}$ & $3.0(0.2) \mathrm{aB}$ & $2.4(0.2) \mathrm{aB}$ & $2.4(0.2) \mathrm{aB}$ \\
\hline $\mathrm{CT}$ & $4.5(0.3) \mathrm{bA}$ & $4.2(0.3) \mathrm{aA}$ & $3.8(0.3) \mathrm{aA}$ & $2.9(0.2) \mathrm{aA}$ & $2.4(0.2) \mathrm{aA}$ \\
\hline Forest & $2.7(0.2)$ & $3.7(0.2)$ & $2.1(0.2)$ & $2.8(0.3)$ & $\begin{array}{l}1.4(0.1) \\
\quad \mathrm{CV}=28.55 \%\end{array}$ \\
\hline & \multicolumn{5}{|c|}{ Inorganic $\mathrm{P}$ extracted by $0.5 \mathrm{~mol} \mathrm{~L}^{-1} \mathrm{NaOH}\left(\mathrm{mg} \mathrm{kg}^{-1}\right)$} \\
\hline NT & $101.3(5.4) \mathrm{aA}^{*}$ & $93.6(6.3) \mathrm{aAB}$ & $88.3(6.8) \mathrm{aB}$ & $83.1(7.0) \mathrm{aB}$ & $85.6(7.6) \mathrm{aB}$ \\
\hline $\mathrm{CT}$ & $86.8(5.7) \mathrm{bA}$ & $87.1(5.9) \mathrm{aA}$ & $88.5(6.2) \mathrm{aA}$ & $83.9(6.5) \mathrm{aA}$ & $87.5(7.6) \mathrm{aA}$ \\
\hline Forest & $113.3(8.9)$ & $96.1(8.1)$ & $94.8(8.5)$ & $93.4(8.7)$ & $\begin{array}{l}98.5(9.5) \\
\mathrm{CV}=13.00 \%\end{array}$ \\
\hline & \multicolumn{5}{|c|}{ Residual inorganic $\mathrm{P}\left(\mathrm{mg} \mathrm{kg}^{-1}\right)$} \\
\hline NT & $555.3(29)$ & $542.6(36)$ & $546.5(42)$ & $524.5(44)$ & $511.3(45)$ \\
\hline $\mathrm{CT}$ & $531.8(35)$ & $562.0(38)$ & $548.8(38)$ & $519.8(40)$ & $533.1(46)$ \\
\hline Mean & $543.6^{\mathrm{ns}}$ & 552.3 & 547.7 & 522.2 & 522.2 \\
\hline Forest & $531.9(42)$ & $508.3(43)$ & $495.9(44)$ & $476.0(44)$ & $\begin{array}{l}512.5(49) \\
\quad \mathrm{CV}=9.98 \%\end{array}$ \\
\hline & \multicolumn{5}{|c|}{ Geochemical P (mg kg-1) } \\
\hline NT & $789(42) \mathrm{aA}^{* *}$ & $696(47) \mathrm{aB}$ & $676(52)$ aBC & $639(54) \mathrm{aC}$ & $625(56) \mathrm{aC}$ \\
\hline $\mathrm{CT}$ & $676(45)$ bAB & $703(48)$ aA & $686(48)$ aAB & $641(50)$ aB & $653(57)$ aAB \\
\hline Forest & $710(56)$ & $648(54)$ & $626(56)$ & $603(56)$ & $\begin{array}{l}644(62) \\
\quad \mathrm{CV}=8.50 \%\end{array}$ \\
\hline \multicolumn{6}{|c|}{ Total P (mg kg-1) } \\
\hline NT & $1887 \mathrm{aA}^{* *}$ & 1488 aB & $1308 \mathrm{bC}$ & $1188 \mathrm{bD}$ & $1125 \mathrm{aD}$ \\
\hline $\mathrm{CT}$ & $1514 \mathrm{bA}$ & 1472 aAB & $1435 \mathrm{aB}$ & $1289 \mathrm{aC}$ & $1155 \mathrm{aD}$ \\
\hline Forest & 1268 & 1189 & 1118 & 1074 & $\begin{array}{l}1039 \\
\mathrm{CV}\end{array}$ \\
\hline
\end{tabular}

(1) Forest (control) data were not included in the statistical analyses. ${ }^{(2)}$ Values in brackets are relative to the total soil P. CT: conventional tillage; NT: no-tillage; ${ }^{*} \mathrm{p}<0.05 ;{ }^{* *} \mathrm{p}<0.01$; Means followed by same letter in the column, comparing soil management for each depth, and means followed by the same capital letter in the same row, comparing the depth within each soil management, were not significantly different at $\mathrm{p}<0.05$ by Tukey's test. 
of $\mathrm{P}$ extracted by $0.1 \mathrm{~mol} \mathrm{~L}^{-1} \mathrm{NaOH}$ from the 0.20 $0.30 \mathrm{~m}$ layer and the content of total $\mathrm{P}$ in the layers $0.10-0.20$ and $0.20-0.30 \mathrm{~m}$, were higher than in NT. Under NT, the labile P extracted with AER from the 0-0.5 $\mathrm{m}$ layer was 4.4 times higher than under $\mathrm{CT}$, and due to the very low vertical mobility of $\mathrm{P}$, the $\mathrm{P}$ content in the soil layers of $0.10-0.20$ and $0.20-0.30 \mathrm{~m}$ was only half of the content found in the soil under CT.

Total P content was higher in the soil under crops than under native vegetation, in all layers evaluated (Table 3). The proportion of inorganic $\mathrm{P}$ to the amount of total $\mathrm{P}$ in the cultivated soil was lower than in the forest (control) soil (49 and $57 \%$ on average, respectively).

The annual application of phosphate fertilizer in the rows of the system without soil disturbance (NT) resulted in higher contents of total $\mathrm{P}$ and all inorganic $\mathrm{P}$ forms, except the recalcitrant non-labile fraction in the soil surface layer than in CT. It is also believed that soil and P losses by erosion are lower in the NT and the P taken up by plants from deeper layers is accumulated on the surface after the decomposition of their residues (Rheinheimer \& Anghinoni, 2001), which may have contributed to the results.
The amount of $\mathrm{P}$ extracted successively by AER decreased exponentially in all cases. Only in the $0-0.05 \mathrm{~m}$ soil layer the amount of potentially available $\mathrm{P}(\beta)$ was higher in NT than in $\mathrm{CT}$ (Table 4).

The $\mathrm{P}$ exchange sites in the soil are finite and have different affinities for phosphate ions. In NT, soluble phosphate applied in the planting rows leads to a region of saturated reactive sites, where much of the phosphate applied is adsorbed with low energy and becomes easily available. In this microregion, there is an increase in $\mathrm{pH}$, deprotonation of functional groups in the surface, creation of negative and reduction of positive charges (Yu, 1997), making them less reactive. In addition, total organic carbon content in the soil surface layer under NT is higher and may decrease the $\mathrm{P}$ adsorption sites through competition with low-molecular-weight organic acids (Jones, 1998; Redel et al., 2007). The set of these factors results in lower energy retention of phosphate when the fertilized soil is not tilled and explains the higher content of $\mathrm{P}$ extracted by water, AER and bicarbonate (labile $\mathrm{P}$ forms) in the 0-0.05 $\mathrm{m}$ layer in NT than in CT. Accordingly, in the desorption of $\mathrm{P}$ from the soil with AER, Rheinheimer et al. (2003) observed that the first extraction removes phosphate adsorbed with less energy and

Table 4. Desorption maximum with anion exchange resin $(\beta)$ and desorption rate constant (k) after 23 years of different soil management and winter crops of a Rhodic Hapludox

\begin{tabular}{|c|c|c|c|c|c|c|c|c|c|}
\hline \multirow{2}{*}{ Soil depth } & \multirow{2}{*}{$\begin{array}{c}\text { Soil } \\
\text { management }\end{array}$} & \multicolumn{6}{|c|}{ Winter crops } & \multirow{2}{*}{ Mean } & \multirow{2}{*}{ Forest $^{(1)}$} \\
\hline & & Oat & Vetch & Radish & Fallow & Lupin & Wheat & & \\
\hline $\mathrm{m}$ & & \multicolumn{8}{|c|}{$\beta\left(\mathrm{mg} \mathrm{kg}^{-1}\right)$} \\
\hline \multirow[t]{2}{*}{$0-0.05$} & NT & $256.7 \mathrm{~A}^{* *}$ & 199.0B & 194.6B & $220.4 \mathrm{~B}$ & $283.0 \mathrm{~A}$ & $164.7 \mathrm{C}$ & $219.7 \mathrm{a}$ & 27.6 \\
\hline & $\mathrm{CT}$ & $60.4 \mathrm{~A}$ & $51.2 \mathrm{~A}$ & $60.1 \mathrm{~A}$ & $70.8 \mathrm{~A}$ & $66.0 \mathrm{~A}$ & 70.9A & $63.2 \mathrm{~b}$ & \\
\hline \multirow[t]{2}{*}{$0.05-0.10$} & NT & $62.5 \mathrm{aAB}$ & $26.5 \mathrm{aC}$ & $34.9 \mathrm{aBC}$ & $40.9 \mathrm{aABC}$ & $70.4 \mathrm{aA}$ & $29.5 \mathrm{aC}$ & & 10.9 \\
\hline & $\mathrm{CT}$ & $30.1 \mathrm{bA}$ & $38.8 \mathrm{aA}$ & $35.1 \mathrm{aA}$ & $37.2 \mathrm{aA}$ & $37.1 \mathrm{bA}$ & $31.3 \mathrm{aA}$ & & \\
\hline \multirow[t]{4}{*}{$0.10-0.20$} & NT & 25.6 & 8.9 & 14.1 & 9.9 & 18.3 & 11.8 & $14.8^{\mathrm{ns}}$ & 6.2 \\
\hline & $\mathrm{CT}$ & 19.8 & 25.0 & 27.2 & 22.2 & 21.8 & 28.0 & 24.0 & \\
\hline & Mean & $22.7^{\mathrm{ns}}$ & 16.9 & 20.6 & 16.0 & 20.1 & 19.9 & & \\
\hline & & & & & \multicolumn{3}{|c|}{$\begin{array}{l}\text { LSD for soil layer }=24.7 \\
\qquad \mathrm{k}\left(\mathrm{dia}^{-1}\right)\end{array}$} & \multicolumn{2}{|c|}{$\mathrm{CV}=18.73 \%$} \\
\hline \multirow[t]{3}{*}{$0-0.05$} & NT & 0.0055 & 0.0052 & 0.0056 & 0.0054 & 0.0055 & 0.0053 & $0.0054 \mathrm{aC}^{* *}$ & 0.0038 \\
\hline & $\mathrm{CT}$ & 0.0041 & 0.0046 & 0.0043 & 0.0040 & 0.0053 & 0.0041 & $0.0044 \mathrm{aB}$ & \\
\hline & Mean & $0.0048^{\mathrm{ns}}$ & 0.0049 & 0.0049 & 0.0047 & 0.0054 & 0.0047 & & \\
\hline \multirow[t]{3}{*}{$0.05-0.10$} & $\mathrm{NT}$ & 0.0079 & 0.0088 & 0.0080 & 0.0065 & 0.0074 & 0.0064 & $0.0075 \mathrm{aB}$ & 0.0062 \\
\hline & $\mathrm{CT}$ & 0.0085 & 0.0078 & 0.0095 & 0.0083 & 0.0077 & 0.0080 & $0.0083 \mathrm{aA}$ & \\
\hline & Mean & $0.0082^{\mathrm{ns}}$ & 0.0083 & 0.0088 & 0.0074 & 0.0075 & 0.0072 & & \\
\hline \multirow[t]{4}{*}{$0.10-0.20$} & NT & 0.0129 & 0.0079 & 0.0077 & 0.0068 & 0.0104 & 0.0106 & $0.0094 \mathrm{aA}$ & 0.0187 \\
\hline & $\mathrm{CT}$ & 0.0120 & 0.0058 & 0.0082 & 0.0086 & 0.0091 & 0.0060 & $0.0079 \mathrm{bA}$ & \\
\hline & Mean & $0.0124^{\mathrm{ns}}$ & 0.0069 & 0.0079 & 0.0077 & 0.0097 & 0.0083 & \multirow{2}{*}{\multicolumn{2}{|c|}{$\mathrm{CV}=26.87 \%$}} \\
\hline & & & & & & & & & \\
\hline
\end{tabular}

(1) Forest (control) data were not included in the statistical analyses. CT: conventional tillage; NT: no-tillage; ${ }^{* *} p<0.01$; Means followed by same letter in the column, comparing soil management for each depth, means followed by same capital letter in the column comparing soil depth for each soil management, and means followed by the same capital letter in the same row, comparing the winter crop within each soil management in each depth were not significantly different at $p<0.05$ by Tukey's test. 
to the extent that it runs out, the removed amount decreases, since the binding energy of the phosphate with colloids increases, leading to an exponentially decaying curve according to the number of successive extractions, as observed in this study. Although the $\mathrm{P}$ availability for plants is enhanced under NT, the accumulation of phosphate on the soil surface poses a great risk of eutrophication of water bodies due to the P-rich colloidal particles carried away by runoff (Panuelas et al., 2009).

By the fertilizer application to the soil under NT, to always the same layer and by the frequent liming of the soil surface in this experiment, the $\mathrm{P}$ concentrations in the region under influence of the diffusion of soil-fertilizer reaction products increased to high enough levels for the neoformation of secondary calcium phosphates of low solubility (Rheinheimer \& Anghinoni, 2001), explaining the higher content of $\mathrm{P}$ extracted by $1.0 \mathrm{~mol} \mathrm{~L}^{-1} \mathrm{HCl}$, from NT than from plowed soil.

Soil plowing prior to each crop in CT distributed the $\mathrm{P}$ applied more evenly in a greater soil volume, resulting in higher total $\mathrm{P}$ content in the layers $0.10-0.20$ and $0.20-0.30 \mathrm{~m}$ than in NT. Thus, in $\mathrm{CT}$ the higher affinity sites for $\mathrm{P}$ in the subsurface are saturated, although much less than in the soil surface layer under NT. However, this was sufficient to increase the level of moderately labile $\mathrm{P}$ extracted by $0.1 \mathrm{~mol} \mathrm{~L}^{-1} \mathrm{NaOH}$ from the $0.20-0.30 \mathrm{~m}$ layer. This demonstrates that $\mathrm{P}$ adsorbed in the soil subsurface under CT has a lower binding energy than under NT. Nevertheless, the higher entry of $\mathrm{P}$ in subsurface CT was not enough to change the content of the $\mathrm{P}$ forms of lower lability, in the forms extracted by $0.5 \mathrm{~mol} \mathrm{~L}^{-1} \mathrm{NaOH}$ and the residual fraction.

The amount of $\mathrm{P}$ exported in maize and soybean grains was $252 \mathrm{~kg} \mathrm{ha}^{-1}$ in NT and $232 \mathrm{~kg} \mathrm{ha}^{-1}$ in $\mathrm{CT}$, despite the non-significant differences in yields (Calegari, 2006). The $\mathrm{P}$ theoretically recovered (potentially available + exported) was higher in the NT (63\%) than in CT (48\%) (Table 5).

The comparison of the theoretical balance of $\mathrm{P}$ between the tillage systems indicates that in soils fertilized for several years under NT, the P that is not exported by crops remains in the soil in forms that are potentially more readily available than in the soil under CT, as observed by Rheinheimer et al. (2000). This occurs because aside from the $\mathrm{P}$ distribution in a larger soil volume in the CT,

Table 5. Phosphorus balance after 23 years of different soil management and winter crops of a Rhodic Hapludox

\begin{tabular}{|c|c|c|c|c|c|c|c|c|c|}
\hline \multirow{2}{*}{$\begin{array}{c}\text { Soil } \\
\text { management }\end{array}$} & \multirow{2}{*}{$\begin{array}{l}\text { Winter } \\
\text { treatment }\end{array}$} & \multirow{2}{*}{ Crop } & \multirow{2}{*}{$\begin{array}{l}\text { Number of } \\
\text { cultivation }\end{array}$} & \multirow{2}{*}{$\begin{array}{l}\text { Average } \\
\text { yeld }^{(1)}\end{array}$} & \multicolumn{5}{|c|}{$\mathbf{P}$} \\
\hline & & & & & Applied(2) & Exported $^{(3)}$ & Available $^{(4)}$ & Recor & $\mathrm{ed}^{(5)}$ \\
\hline \multirow{4}{*}{ NT } & \multirow{4}{*}{ Oat/lupin } & & & & 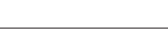 & $\mathrm{kg} \mathrm{ha}^{-1}$ & & 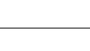 & $\%$ \\
\hline & & Maize & 9 & 6359 & 270 & 126 & & & \\
\hline & & Soybean & 13 & 2651 & 390 & 134 & & & \\
\hline & & Total & & & 660 & 260 & 197 & 457 & 69 \\
\hline \multirow[t]{3}{*}{ NT } & \multirow{3}{*}{$\begin{array}{l}\text { Vetch/ } \\
\text { radish/ } \\
\text { fallow }\end{array}$} & Maize & 9 & 6089 & 270 & 121 & & & \\
\hline & & Soybean & 13 & 2582 & 390 & 131 & & & \\
\hline & & Total & & & 660 & 252 & 141 & 393 & 60 \\
\hline \multirow[t]{4}{*}{ NT } & \multirow[t]{4}{*}{ Wheat } & Maize & 9 & 5806 & 270 & 115 & & & \\
\hline & & Soybean & 13 & 2529 & 390 & 128 & & & \\
\hline & & Wheat & 7 & 1800 & 0 & 35 & & & \\
\hline & & Total & & & 660 & 278 & 123 & 402 & 61 \\
\hline \multirow[t]{3}{*}{$\mathrm{CT}$} & \multirow[t]{3}{*}{$\operatorname{Mean}^{(6)}$} & Maize & 9 & 5717 & 270 & 113 & & & \\
\hline & & Soybean & 13 & 1974 & 390 & 119 & & & \\
\hline & & Total & & & 660 & 232 & 84 & 316 & 48 \\
\hline
\end{tabular}

(1) Yeld data obtained from Calegari (2006). (2) Amount of P applied in fertilizer from 1986 to 2009 (30 kg ha ${ }^{-1}$ of P/ maize or soybean crop). (3) Amount of $\mathrm{P}$ exported in grains, considering a content of $2.2,3.9$ and $2.8 \mathrm{~g} \mathrm{~kg}^{-1} \mathrm{P}$ of maize, soybean and wheat grain, respectively (CQFSRS/SC, 2004). (4) Available $\mathrm{P}$ in the 0-0.20 m layer = maximum desorption of $\mathrm{P}$ with anion exchange resin (AER), considering soil mass as a function of soil bulk density and the layer volume. ${ }^{(5)}$ Recovered $\mathrm{P}=$ exported $\mathrm{P}+\mathrm{P}$ desorbed with $\mathrm{AER}$. (6) Average of all winter crops. 
more soil and $\mathrm{P}$ can be lost by erosion and, as in the present study, less $\mathrm{P}$ exported by grains in the CT.

The increase in total $\mathrm{P}$ content together with the decreasing proportion of inorganic $\mathrm{P}$ in crop compared to forest soil indicated that $\mathrm{P}$ applied via fertilizer was not accumulated in inorganic forms.

\section{Effect of winter crops}

Under blue lupin and oat under NT in the winter the $0-0.05 \mathrm{~m}$ layer contained more $\mathrm{P}$ extracted by distilled water, $\mathrm{AER}, \mathrm{NaHCO}_{3}$ and $\mathrm{HCl}$, than under the other winter crops. In the layer $0.05-0.10 \mathrm{~m}$, higher levels of $\mathrm{P}$ were extracted by $\mathrm{HCl}$ and by AER only under blue lupin (Tables 6 and 7). The recovery of $\mathrm{P}$ extracted by $0.1 \mathrm{~mol} \mathrm{~L}^{-1} \mathrm{NaOH}$ was also higher under blue lupin, independent of the soil management and sampled layer (Table 8), compared to the other winter crops. However, the cultivation of different plant species did not alter the content of lower lability $\mathrm{P}$ forms $\left(0.5 \mathrm{~mol} \mathrm{~L}^{-1} \mathrm{NaOH}\right.$ and residual fraction) or the total content of $\mathrm{P}$ in soil.

In the NT, the amount of potentially available $\mathrm{P}$ was higher in the soil layers down to $0.10 \mathrm{~m}$ under blue lupin and oat, and lower in the soil layer of 0-0.05 m under wheat, compared to the other winter

Table 6. Phosphorus extracted by distilled water and by anion exchange resin (AER) after 23 years of different soil management and winter crops of a Rhodic Hapludox

\begin{tabular}{|c|c|c|c|c|c|c|c|c|c|}
\hline \multirow[b]{2}{*}{ Soil depth } & \multirow{2}{*}{$\begin{array}{c}\text { Soil } \\
\text { management }\end{array}$} & \multicolumn{6}{|c|}{ Winter crop } & \multirow[b]{2}{*}{ Mean } & \multirow[b]{2}{*}{ Forest $^{1}$} \\
\hline & & Oat & Vetch & Radish & Fallow & Lupin & Wheat & & \\
\hline $\mathrm{m}$ & & \multicolumn{8}{|c|}{ Inorganic $\mathrm{P}$ extracted by distilled water $\left(\mathrm{mg} \mathrm{kg}^{-1}\right)$} \\
\hline \multirow[t]{2}{*}{$0-0.05$} & NT & $2.33 \mathrm{~A}^{* *}$ & $1.24 \mathrm{~B}$ & $1.37 \mathrm{~B}$ & $1.00 \mathrm{~B}$ & $2.08 \mathrm{~A}$ & $0.92 \mathrm{~B}$ & $1.49 \mathrm{a}$ & \multirow[t]{2}{*}{0.75} \\
\hline & $\mathrm{CT}$ & $0.47 \mathrm{~A}$ & $0.46 \mathrm{~A}$ & $0.44 \mathrm{~A}$ & $0.46 \mathrm{~A}$ & $0.52 \mathrm{~A}$ & $0.56 \mathrm{~A}$ & $0.48 \mathrm{~b}$ & \\
\hline \multirow[t]{3}{*}{$0.05-0.10$} & NT & 0.40 & 0.43 & 0.49 & 0.37 & 0.70 & 0.51 & $0.48^{\mathrm{ns}}$ & \multirow[t]{3}{*}{0.62} \\
\hline & $\mathrm{CT}$ & 0.51 & 0.51 & 0.50 & 0.20 & 0.54 & 0.37 & 0.44 & \\
\hline & Mean & $0.45^{\mathrm{ns}}$ & 0.47 & 0.50 & 0.29 & 0.62 & 0.44 & & \\
\hline \multirow[t]{3}{*}{$0.10-0.20$} & NT & 0.64 & 0.31 & 0.46 & 0.28 & 0.41 & 0.52 & $0.44^{\mathrm{ns}}$ & \multirow[t]{3}{*}{0.34} \\
\hline & $\mathrm{CT}$ & 0.65 & 0.41 & 0.44 & 0.29 & 0.39 & 0.28 & 0.41 & \\
\hline & Mean & $0.65^{\mathrm{ns}}$ & 0.36 & 0.45 & 0.28 & 0.40 & 0.40 & & \\
\hline \multirow[t]{3}{*}{$0.20-0.30$} & $\mathrm{NT}$ & 0.50 & 0.12 & 0.46 & 0.12 & 0.25 & 0.28 & $0.29^{\mathrm{ns}}$ & \multirow[t]{3}{*}{0.12} \\
\hline & $\mathrm{CT}$ & 0.42 & 0.22 & 0.28 & 0.24 & 0.32 & 0.33 & 0.30 & \\
\hline & Mean & $0.46^{\mathrm{ns}}$ & 0.17 & 0.37 & 0.18 & 0.28 & 0.30 & & \\
\hline \multirow[t]{4}{*}{$0.30-0.40$} & NT & 0.20 & 0.05 & 0.18 & 0.06 & 0.21 & 0.07 & $0.13^{\mathrm{ns}}$ & \multirow[t]{2}{*}{0.12} \\
\hline & $\mathrm{CT}$ & 0.39 & 0.14 & 0.16 & 0.23 & 0.16 & 0.11 & 0.20 & \\
\hline & Mean & $0.29^{\mathrm{ns}}$ & 0.10 & 0.17 & \multicolumn{2}{|c|}{$\begin{array}{ll}0.15 & 0.18 \\
\text { LSD for soil layer } & =0.38\end{array}$} & 0.09 & \multicolumn{2}{|c|}{$\mathrm{CV}(\%)=35.48$} \\
\hline & & \multicolumn{8}{|c|}{ Inorganic P extracted by AER (mg kg-1) } \\
\hline \multirow[t]{2}{*}{$0-0.05$} & NT & $50.6 \mathrm{~B}^{* *}$ & $41.9 \mathrm{C}$ & $36.9 \mathrm{C}$ & $37.4 \mathrm{C}$ & $63.7 \mathrm{~A}$ & $36.8 \mathrm{C}$ & $44.6 \mathrm{a}$ & \multirow[t]{2}{*}{11.5} \\
\hline & $\mathrm{CT}$ & $9.9 \mathrm{~A}$ & $8.1 \mathrm{~A}$ & $12.8 \mathrm{~A}$ & $9.7 \mathrm{~A}$ & $12.5 \mathrm{~A}$ & $10.8 \mathrm{~A}$ & $10.6 \mathrm{~b}$ & \\
\hline \multirow[t]{2}{*}{$0.05-0.10$} & NT & $11.6 \mathrm{aB}$ & $7.5 \mathrm{aB}$ & $10.6 \mathrm{aB}$ & $9.9 \mathrm{aB}$ & $19.0 \mathrm{aA}$ & $11.6 \mathrm{aB}$ & & \multirow[t]{2}{*}{4.4} \\
\hline & $\mathrm{CT}$ & $7.6 \mathrm{aA}$ & $8.9 \mathrm{aA}$ & $12.0 \mathrm{aA}$ & $9.3 \mathrm{aA}$ & $10.1 \mathrm{bA}$ & $7.7 \mathrm{aA}$ & & \\
\hline \multirow[t]{3}{*}{$0.10-0.20$} & NT & 4.0 & 1.6 & 3.6 & 1.9 & 6.8 & 2.4 & $3.4^{\mathrm{ns}}$ & \multirow[t]{3}{*}{1.9} \\
\hline & $\mathrm{CT}$ & 4.7 & 5.7 & 7.9 & 6.4 & 7.1 & 6.8 & 6.4 & \\
\hline & Mean & $4.3^{\mathrm{ns}}$ & 3.7 & 5.8 & 4.2 & 7.0 & 4.6 & & \\
\hline \multirow[t]{3}{*}{$0.20-0.30$} & NT & 1.9 & 0.9 & 1.0 & 0.8 & 2.1 & 0.6 & $1.2^{\mathrm{ns}}$ & \multirow[t]{3}{*}{1.2} \\
\hline & $\mathrm{CT}$ & 1.6 & 2.3 & 2.8 & 2.4 & 3.6 & 2.0 & 2.5 & \\
\hline & Mean & $1.7^{\mathrm{ns}}$ & 1.6 & 1.9 & 1.6 & 2.9 & 1.3 & & \\
\hline \multirow[t]{4}{*}{$0.30-0.40$} & NT & 0.5 & 0.9 & 1.2 & 0.5 & 1.3 & 0.6 & 0.8 & 1.0 \\
\hline & $\mathrm{CT}$ & 0.9 & 1.5 & 1.1 & 0.8 & 1.4 & 0.7 & 1.1 & \\
\hline & Mean & $0.7^{\mathrm{ns}}$ & 1.2 & 1.2 & 0.6 & 1.4 & 0.6 & & \\
\hline & & & & & LSD for soi & $\mathrm{er}=6.6$ & & CV $\left({ }^{\circ}\right.$ & $=31.41$ \\
\hline
\end{tabular}

CT: conventional tillage; NT: no-tillage; ${ }^{n s}$ : not significant; ${ }^{* *} \mathrm{p}<0.01$; Means followed by same letter in the column, comparing soil management for each depth, and means followed by the same capital letter in the same row, comparing the winter crop within each soil management in each depth were not significantly different at $\mathrm{p}<0.05$ by Tukey's test; ${ }^{1}$ Forest (control) data were not included in the statistical analyses. 
Table 7. Phosphorus extracted by $\mathrm{NaHCO}_{3}$ and by $\mathrm{HCl}$ after 23 years of different soil management and winter crops of a Rhodic Hapludox

\begin{tabular}{|c|c|c|c|c|c|c|c|c|c|}
\hline \multirow{2}{*}{ Soil depth } & \multirow{2}{*}{$\begin{array}{c}\text { Soil } \\
\text { management }\end{array}$} & \multicolumn{6}{|c|}{ Winter crop } & \multirow{2}{*}{ Mean } & \multirow{2}{*}{ Forest $^{(1)}$} \\
\hline & & Oat & Vetch & Radish & Fallow & Lupin & Wheat & & \\
\hline $\mathrm{m}$ & & \multicolumn{8}{|c|}{ Inorganic $\mathrm{P}$ extracted by $0.5 \mathrm{~mol} \mathrm{~L}^{-1} \mathrm{NaHCO}_{3}$ at $\mathrm{pH} 8.5\left(\mathrm{mg} \mathrm{kg}^{-1}\right)$} \\
\hline $0-0.05$ & $\begin{array}{l}\mathrm{NT} \\
\mathrm{CT}\end{array}$ & $\begin{array}{c}14.1 \mathrm{~A}^{*} \\
5.3 \mathrm{~A}\end{array}$ & $\begin{array}{r}10.9 \mathrm{~B} \\
5.6 \mathrm{~A}\end{array}$ & $\begin{array}{r}11.3 \mathrm{~B} \\
5.2 \mathrm{~A}\end{array}$ & $\begin{array}{r}11.6 \mathrm{~B} \\
6.4 \mathrm{~A}\end{array}$ & $\begin{array}{c}11.9 \mathrm{AB} \\
5.5 \mathrm{~A}\end{array}$ & $\begin{array}{l}9.6 \mathrm{~B} \\
6.6 \mathrm{~A}\end{array}$ & $\begin{array}{r}11.6 \mathrm{a} \\
5.7 \mathrm{~b}\end{array}$ & 8.4 \\
\hline $0.05-0.10$ & $\begin{array}{l}\text { NT } \\
\text { CT } \\
\text { Mean }\end{array}$ & $\begin{array}{l}5.8 \\
4.6 \\
5.2^{\mathrm{ns}}\end{array}$ & $\begin{array}{l}5.8 \\
5.8 \\
5.8\end{array}$ & $\begin{array}{l}5.2 \\
6.1 \\
5.7\end{array}$ & $\begin{array}{l}4.7 \\
4.7 \\
4.7\end{array}$ & $\begin{array}{l}6.5 \\
6.2 \\
6.4\end{array}$ & $\begin{array}{l}6.0 \\
4.5 \\
5.3\end{array}$ & $\begin{array}{l}5.7^{\mathrm{ns}} \\
5.3\end{array}$ & 5.1 \\
\hline $0.10-0.20$ & $\begin{array}{l}\text { NT } \\
\text { CT } \\
\text { Mean }\end{array}$ & $\begin{array}{l}2.7 \\
4.0 \\
3.4^{\mathrm{ns}}\end{array}$ & $\begin{array}{l}3.3 \\
5.0 \\
4.1\end{array}$ & $\begin{array}{l}4.5 \\
5.0 \\
4.8\end{array}$ & $\begin{array}{l}2.9 \\
4.4 \\
3.6\end{array}$ & $\begin{array}{l}4.3 \\
5.2 \\
4.7\end{array}$ & $\begin{array}{l}4.1 \\
4.4 \\
4.2\end{array}$ & $\begin{array}{l}3.6^{\mathrm{ns}} \\
4.6\end{array}$ & 3.2 \\
\hline $0.20-0.30$ & $\begin{array}{l}\text { NT } \\
\text { CT } \\
\text { Mean }\end{array}$ & $\begin{array}{l}2.4 \\
2.9 \\
2.6^{\mathrm{ns}}\end{array}$ & $\begin{array}{l}3.2 \\
3.9 \\
3.5\end{array}$ & $\begin{array}{l}3.3 \\
3.1 \\
3.2\end{array}$ & $\begin{array}{l}2.2 \\
3.9 \\
3.0\end{array}$ & $\begin{array}{l}2.9 \\
3.8 \\
3.4\end{array}$ & $\begin{array}{l}3.4 \\
3.0 \\
3.2\end{array}$ & $\begin{array}{l}2.9^{\mathrm{ns}} \\
3.4\end{array}$ & 2.8 \\
\hline \multirow[t]{2}{*}{$0.30-0.40$} & $\begin{array}{l}\text { NT } \\
\text { CT } \\
\text { Mean }\end{array}$ & $\begin{array}{l}1.4 \\
2.5 \\
1.9^{\mathrm{ns}}\end{array}$ & $\begin{array}{l}3.0 \\
3.9 \\
3.5\end{array}$ & $\begin{array}{l}3.6 \\
3.2 \\
3.4\end{array}$ & $\begin{array}{l}2.8 \\
3.5 \\
3.2\end{array}$ & $\begin{array}{l}2.3 \\
3.2 \\
2.7\end{array}$ & $\begin{array}{l}2.6 \\
2.5 \\
2.5\end{array}$ & $\begin{array}{l}2.6^{\mathrm{ns}} \\
3.1\end{array}$ & 3.0 \\
\hline & & & & & LSD for so & ayer $=2.3$ & & $\mathrm{CV}(\%$ & $\%)=20.66$ \\
\hline $0-0.05$ & $\begin{array}{l}\mathrm{NT} \\
\mathrm{CT}\end{array}$ & $\begin{array}{l}19.2 \mathrm{AB}^{*} \\
5.7 \mathrm{~A}\end{array}$ & $\begin{array}{c}13.2 \mathrm{C} \\
3.1 \mathrm{~A}\end{array}$ & $\begin{array}{c}\text { organic P } \\
18.5 \mathrm{~B} \\
4.9 \mathrm{~A}\end{array}$ & $\begin{array}{c}\text { extracted b } \\
14.6 \mathrm{C} \\
3.6 \mathrm{~A}\end{array}$ & $\begin{array}{c}.0 \mathrm{~mol} \mathrm{~L}^{-1} \\
21.9 \mathrm{~A} \\
4.2 \mathrm{~A}\end{array}$ & $\begin{array}{c}\mathrm{Cl}\left(\mathrm{mg} \mathrm{kg}^{-1}\right. \\
13.7 \mathrm{C} \\
5.7 \mathrm{~A}\end{array}$ & $\begin{array}{r}16.8 \mathrm{a} \\
4.5 \mathrm{~b}\end{array}$ & 2.7 \\
\hline $0.05-0.10$ & $\begin{array}{l}\mathrm{NT} \\
\mathrm{CT}\end{array}$ & $\begin{array}{l}6.7 \mathrm{aAB} \\
5.3 \mathrm{aA}\end{array}$ & $\begin{array}{l}3.6 \mathrm{aB} \\
2.9 \mathrm{aA}\end{array}$ & $\begin{array}{l}5.2 \mathrm{aB} \\
4.4 \mathrm{aA}\end{array}$ & $\begin{array}{l}3.6 \mathrm{aB} \\
4.4 \mathrm{aA}\end{array}$ & $\begin{array}{l}8.0 \mathrm{aA} \\
3.8 \mathrm{bA}\end{array}$ & $\begin{array}{l}5.9 \mathrm{aAB} \\
4.3 \mathrm{aA}\end{array}$ & & 3.7 \\
\hline $0.10-0.20$ & $\begin{array}{l}\text { NT } \\
\text { CT } \\
\text { Mean }\end{array}$ & $\begin{array}{l}4.0 \\
4.6 \\
4.3^{\mathrm{ns}}\end{array}$ & $\begin{array}{l}1.7 \\
2.5 \\
2.1\end{array}$ & $\begin{array}{l}2.3 \\
4.7 \\
3.5\end{array}$ & $\begin{array}{l}2.5 \\
3.4 \\
2.9\end{array}$ & $\begin{array}{l}3.8 \\
3.7 \\
3.8\end{array}$ & $\begin{array}{l}3.6 \\
4.1 \\
3.8\end{array}$ & $\begin{array}{l}3.0^{\mathrm{ns}} \\
3.8^{-}\end{array}$ & 2.1 \\
\hline $0.20-0.30$ & $\begin{array}{l}\text { NT } \\
\text { CT } \\
\text { Mean }\end{array}$ & $\begin{array}{l}4.2 \\
3.8 \\
4.0^{\text {ns }}\end{array}$ & $\begin{array}{l}1.2 \\
2.4 \\
1.8\end{array}$ & $\begin{array}{l}1.6 \\
2.8 \\
2.2\end{array}$ & $\begin{array}{l}2.8 \\
2.8 \\
2.8\end{array}$ & $\begin{array}{l}2.0 \\
3.0 \\
2.5\end{array}$ & $\begin{array}{l}2.7 \\
2.6 \\
2.6\end{array}$ & $\begin{array}{l}2.4^{\mathrm{ns}} \\
2.9\end{array}$ & 2.8 \\
\hline $0.30-0.40$ & $\begin{array}{l}\text { NT } \\
\text { CT } \\
\text { Mean }\end{array}$ & $\begin{array}{l}4.0 \\
3.0 \\
3.5^{\mathrm{ns}}\end{array}$ & $\begin{array}{l}1.3 \\
3.2 \\
2.2\end{array}$ & $\begin{array}{l}2.0 \\
1.7 \\
1.8\end{array}$ & $\begin{array}{l}2.5 \\
2.9 \\
2.7\end{array}$ & $\begin{array}{l}2.3 \\
1.6 \\
1.9\end{array}$ & $\begin{array}{l}2.1 \\
2.0 \\
2.1\end{array}$ & $\begin{array}{l}2.4^{\mathrm{ns}} \\
2.4^{4}\end{array}$ & 1.4 \\
\hline & & & & & LSD for $\mathrm{s}$ & yer $=3.1$ & & & \\
\hline
\end{tabular}

(1) Forest (control) data were not included in the statistical analyses. CT: conventional tillage; NT: no-tillage; ns: not significant; ${ }^{*}$ $\mathrm{p}<0.05$; Means followed by same letter in the column, comparing soil management for each depth, and means followed by the same capital letter in the same row, comparing the winter crop within each soil management in each depth were not significantly different at $\mathrm{p}<0.05$ by Tukey's test.

crops (Table 4). The desorption rate constant was not affected by the winter crops.

The higher content of labile $\mathrm{P}$ forms in soil surface layers under NT with black oat and blue lupin cannot be attributed to the lower export of $\mathrm{P}$ by grain yield of summer crops, as reported by Rheinheimer \& Anghinoni (2001). In this study, the amount/grain yield of maize ( 8 crops) and soybeans (9 crops) grains produced in the soil under NT was not affected by the winter crops (Calegari, 2006). Nevertheless, oat produced large amounts of dry matter from 1986 to 2005; over the course of the 11 years in which all winter species were grown, black oat accumulated $15 \mathrm{Mg} \mathrm{ha}^{-1}$ of residue more than the other cultivated species (Calegari, 2006).
These residues probably cycled a larger amount of $\mathrm{P}$, resulting in the higher content of labile $\mathrm{P}$ forms in soil surface layers under NT.

Lupin is known for excreting large amounts of organic acids such as citrate, malate and fumarate, even at relatively high $\mathrm{P}$ availability (Bayon et al., 2006), which promotes the mobilization of $P$ by ligand exchange and/or by dissolving and occupying adsorption sites. Consequently, lupin can access inorganic $\mathrm{P}$ forms that are inaccessible to other plants. Thus, lupin may also cycle large amounts of $\mathrm{P}$, which may have increased the concentration of labile $\mathrm{P}$ forms in the soil surface layers under NT. However, in the CT, plowing distributed the organic residues in the deeper layers, with the consequent 
Table 8. Forms of inorganic phosphorus and total phosphorus after 23 years of different winter crops of a Rhodic Hapludox

\begin{tabular}{|c|c|c|c|c|c|}
\hline \multirow{2}{*}{ Winter crop } & \multicolumn{4}{|c|}{ Form of inorganic phosphorus } & \multirow{2}{*}{$\begin{array}{c}\text { Total } \\
\text { phosphorus }\end{array}$} \\
\hline & $\mathrm{NaOH} 0.1$ & $\mathrm{NaOH} 0.5$ & Residual & Geochemical & \\
\hline & \multicolumn{5}{|c|}{$\mathrm{P}\left(\mathrm{mg} \mathrm{kg}^{-1}\right)$} \\
\hline Oat & $31.3 \mathrm{~b}^{* *}$ & $85.7^{\mathrm{ns}}$ & $499.7^{\mathrm{ns}}$ & $636.6^{\mathrm{ns}}$ & $1332^{\text {ns }}$ \\
\hline Vetch & $32.6 \mathrm{~b}$ & 96.6 & 565.4 & 711.1 & 1442 \\
\hline Radish & $34.0 \mathrm{~b}$ & 85.7 & 550.5 & 689.0 & 1270 \\
\hline Fallow & $31.3 \mathrm{~b}$ & 82.3 & 542.1 & 672.6 & 1434 \\
\hline Lupin & $41.8 \mathrm{a}$ & 95.4 & 542.2 & 702.8 & 1403 \\
\hline Wheat & $30.3 \mathrm{~b}$ & 85.6 & 525.6 & 658.9 & 1435 \\
\hline Mean & $33.5(2.4)^{(2)}$ & $88.6(6.4)$ & $537.6(39)$ & $678.5(49)$ & 1386 \\
\hline Forest ${ }^{(1)}$ & $30.9(2.7)$ & $99.2(8.7)$ & $504.9(44)$ & $646.1(57)$ & 1138 \\
\hline $\mathrm{CV}(\%)$ & 17.16 & 23.25 & 15.90 & 14.05 & 17.26 \\
\hline
\end{tabular}

(1) Forest (control) data were not included in the statistical analyses; ${ }^{2}$ Values in brackets are relative to the total soil P. ns: not significant; ${ }^{* *} \mathrm{p}<0.01$; Means followed by the same letter in the column comparing winter crops were not significantly different at $\mathrm{p}<0.05$ by Tukey's test.

reactions of $\mathrm{P}$ with the soil after mineralization, which is why the content of labile $\mathrm{P}$ forms under black oat and lupin was not higher.

In a comparison of the amount of potentially available $\mathrm{P}$ in the $0-0.05 \mathrm{~m}$ layer of the winter crops, three groups were formed: black oat and lupin, with the highest amount of potentially available soil $\mathrm{P}$, followed by oilseed radish, vetch and fallow, and wheat, which in turn, had the lowest content of potentially available $\mathrm{P}$ among the winter crops. However, the amount of $\mathrm{P}$ recovered theoretically (potentially available + exported) from soil under wheat was very similar to the amount recovered from the soil with oilseed radish, vetch and fallow (61 and $60 \%$ respectively), probably due to the $\mathrm{P}$ exported by seven wheat harvests, between 1986 and 1995.

\section{CONCLUSIONS}

1. Phosphate fertilization in the row in NT increased inorganic $\mathrm{P}$ in the labile and moderately labile forms, and soil disturbance in the CT redistributed $\mathrm{P}$ applied to deeper layers, promoting an increase in the moderately labile $\mathrm{P}$ concentration in soil subsurface layers.

2. Black oat and blue lupin were most efficient in $\mathrm{P}$ cycling, and when grown under NT increased the content of labile $\mathrm{P}$ in soil surface layers.

\section{LITERATURE CITED}

BAYON, R.C.; WEISSKOPF, L.; MARTINOIA, E.; JANSA, J.; FROSSARD, E.; KELLER, F.; FÖLLMI, K.B. \& GOBAT, J.M. Soil phosphorus uptake by continuously cropped $\mathrm{Lu}$ pinus albus: A new microcosm design. Plant Soil, 283:309321, 2006.

BROOKES, P.C. \& POWLSON, D.C. Preventing phosphorus losses during perchloric acid digestion of sodium bicarbonate soil extracts. J. Sci. Food Agric., 32:671-674, 1982.

CALEGARI, A. Sequestro de carbono, atributos físicos e químicos em diferentes sistemas de manejo em um Latossolo argiloso do sul do Brasil. Londrina, Universidade de Londrina, 2006. 191p. (Tese de Doutorado)

COMISSÃO DE QUÍMICA E FERTILIDADE DO SOLO CQFSRS/SC. Manual de adubação e de calagem para os Estados do Rio Grande do Sul e Santa Catarina. 10.ed. Porto Alegre, Sociedade Brasileira de Ciência do Solo/Núcleo Regional Sul, 2004. 400p.

COSTA, A.C.S. Iron oxide mineralogy of soils derived from volcanic rocks in the Paraná River Basin, Brazil. Columbus, The Ohio State University, 1996. 243p. (Tese de Doutorado)

DICK, W.A. \& TABATABAI, M.A. Determination of orthophosphate in aqueous solutions containing labile organic and inorganic phosphorus compounds. J. Environ. Qual., 6:82-85, 1977.

GATIBONI, L.C.; KAMINSKI, J.; RHEINHEIMER, D.S. \& SAGGIN, A. Quantificação do fósforo disponível por extrações sucessivas com diferentes extratores em Latossolo Vermelho distroférrico, R. Bras. Ci. Solo, 26:1023-1029, 2002. 
GATIBONI, L.C.; KAMINSKI, J.; RHEINHEIMER, D.S. \& FLORES, J.P.C. Biodisponibilidade de formas de fósforo acumuladas em solo sob sistema plantio direto. R. Bras. Ci. Solo, 31:691-699, 2007.

HEDLEY, M.J.; STEWART, J.W.B. \& CHAUHAN, B.S. Changes in inorganic and organic soil phosphorus fractions induced by cultivation practices and by laboratory incubations. Soil Sci. Soc. Am. J., 46:970-976, 1982.

HORST, W.J.; KAMH, M.; JIBRIN, J.M. \& CHUDE, V.O. Agronomic measures for increasing $\mathrm{P}$ availability to crops. Plant Soil, 237:211-223, 2001.

JONES, D.L. Organic acids in the rhizosphere - a critical review. Plant Soil, 205:25-44, 1998.

KUO, S.; HUANG, B. \& BEMBENEK, R. Effects of long-term phosphorus fertilization and winter cover cropping on soil phosphorus transformations in less weathered soil. Biol. Fert. Soils, 41:116-123, 2005.

LAJTHA, K. \& HARRISON, A.F. Strategies of phosphorus acquisition and conservation by plant species and communities. In: TIESSEN, H., ed. Phosphorus in the global environmental: Transfers, cycles and management. Chichester, Wiley, 1995. p.139-147.

LI, H.; SHEN, J.; ZHANG, F.; MARSCHNER, P.; CAWTHRAY, G. \& RENGEL, Z. Phosphorus uptake and rhizosphere properties of intercropped and monocropped maize, faba bean, and white Lupin in acidic soil. Biol. Fert. Soils, 46:79-91, 2010.

McKEAN, J. \& WARREN, G.P. Determination of phosphate desorption characteristics in soils using successive resin extractions. Comm. Soil Sci. Plant Anal., 27:2397-2417, 1996.

MURPHY, J. \& RILEY, J.P. A modified single solution method for the determination of phosphate in natural waters. Anal. Chim. Acta, 27:31-36, 1962.

OLSEN, S.R. \& SOMMERS, L.E. Phosphorus. In: PAGE, A.L.; MILLER, R. H. \& KEENEY, Q.R., eds. Methods of soil analysis. Chemical and microbiological properties. 2.ed. Madison, American Society of Agronomy, 1982. Part 2. p.403-430. (Agronomy Monograph, 9)

PANUELAS, J.; SARDANS, J.; ALCANIZ, J.M. \& POCH, J.M. Increased eutrophication and nutrient imbalances in the agricultural soil of NE Catalonia, Spain. J. Environ. Biol., 30:841-846, 2009.

REDEL Y.D.; RUBIO, R.; ROUANET, J.L. \& BORIE, F. Phosphorus bioavailability affected by tillage and crop rotation on a Chilean volcanic derived Ultisol. Geoderma, 139:388$396,2007$.

RHEINHEIMER, D.S. Dinâmica do fósforo em sistemas de manejo de solos. Porto Alegre, Universidade Federal do Rio Grande do Sul, 2000. 210p. (Tese de Doutorado)
RHEINHEIMER, D.S.; ANGHINONI, I. \& KAMINSKI, J. Depleção do fósforo inorgânico de diferentes frações provocada pela extração sucessiva com resina em diferentes solos e manejos. R. Bras. Ci. Solo, 24:345-354, 2000.

RHEINHEIMER, D.S. \& ANGHINONI, I. Distribuição do fósforo inorgânico em sistemas de manejo de solo. Pesq. Agropec. Bras., 36:151-160, 2001.

RHEINHEIMER, D.S.; ANGHINONI, I.; CONTE, E.; KAMINSKI, J. \& GATIBONI, L.C. Dessorção de fósforo avaliada por extrações sucessivas em amostras de solo provenientes dos sistemas plantio direto e convencional. Ci. Rural, 33:1053-1059, 2003.

ROSE, T.J.; HARDIPUTRA, B. \& RENGEL, Z. Wheat, canola and grain legume access to soil phosphorus fractions differs in soils with contrasting phosphorus dynamics. Plant Soil, 326:159-170, 2010.

SILVA, F.A.S. \& AZEVEDO, C.A.V.A. New version of the Assistat-Statistical Assistance Software. In: WORLD CONGRESS ON COMPUTERS IN AGRICULTURE, 4., Orlando, 2006. Anais... Orlando, American Society of Agricultural and Biological Engineers, 2006. p.393-396.

TAKEDA, M. Phosphorus transformation in a soybean-cropping system in Andosol: Effects of winter cover cropping and compost application. Nutr. Cycl. Agroec., 85:287-297, 2009.

TIESSEN, H.; STEWART, J.W.B. \& COLE, C.V. Pathways of phosphorus transformations in soils of differing pedogenesis. Soil Sci. Soc. Am. J., 48:853-858, 1984.

VINCENT, A.G.; TURNERB, B.L. \& TANNER, E.V.J. Soil organic phosphorus dynamics following perturbation of litter cycling in a tropical moist Forest. Europ. J. Soil Sci., 61:48-57, 2010.

WANG, J.; LIU, W.Z.; MU, H.F. \& DANG, T.H. Inorganic phosphorus fractions and phosphorus availability in a calcareous soil receiving 21-years superphosphate application. Pedosphere, 20:304-310, 2010.

WANG, X.; TANG, C.; GUPPY, C.N. \& SALE, P.W.G. Phosphorus acquisition characteristics of cotton (Gossypium hirsutum L.), wheat (Triticum aestivum L.) and white lupin (Lupinus albus L.) under P deficient conditions. Plant Soil, 312:117128,2008

YU, T.R. Chemistry of variable charge soils. New York, Oxford University Press, 1997. 505p.

ZAMUNER, E.C.; PICONE, L.I. \& ECHEVERRIA, H.E. Organic and inorganic phosphorus in Mollisol soil under different tillage practices, Soil Tillage Res., 99:131-138, 2008. 
